\title{
Polisaccharides from Cystocarpic Plants of the Red Seaweed Callophyllis Variegata
}

\author{
E. R. Merino, A. S. Cerezo and M. C. Matulewicz \\ Departamento de Química Orgánica, CIHIDECAR-CONICET, Facultad de Ciencias Exactas y Natu- \\ rales, Universidad de Buenos Aires, Pabellón 2, Ciudad Universitaria, 1428 Buenos Aires, Argentina \\ E-mail: emlia@qo.fcen.uba.ar
}

\begin{abstract}
The crude polysaccharide from cystocarpic Callophyllis variegata was fractionated with potassium chloride yielding three minor fractions which precipitated between $0.05-0.10 \mathrm{M} \mathrm{KCl}, 1.20-1.25 \mathrm{M} \mathrm{KCl}$ and $1.80-2.00 \mathrm{M} \mathrm{KCl}$, and a main product soluble in 2.00 $\mathrm{M} \mathrm{KCl}$. These fractions were analysed and structural analysis of the major one was carried out by methylation, FT-IR and ${ }^{13} \mathrm{C}$ NMR.
\end{abstract}

\section{Introduction}

Callophyllis variegata belongs to the family Kallymeniaceae and there are only two previous studies [1,2] on seaweeds from the same genus, Callophyllis rhynchocarpa and Callophyllis hombroniana. These studies report the isolation of carrageenan-type polysaccharides.

\section{Experimental}

The crude polysaccharide and the fractions were analyzed using the methods mentioned in ref. [3]. The fraction soluble in $2.00 \mathrm{M} \mathrm{KCl}$ was converted into the corresponding triethylammonium salt and was methylated by the Hakomori procedure as described in ref. [3]. The samples were subjected to reductive hydrolysis and further acetylation, and were analyzed by GC [3]. The D:L-galactose ratio was determined by the method of ref. [4].

\section{Results and discussion}

Cystocarpic plants of Callophyllis variegata, collected in Puerto Deseado (Provincia de Santa Cruz), were extracted with water at room temperature and the crude product was analyzed (carbohydrate content, sulphate, primary sulphate and protein; composition in monosaccharides, D:L-galactose ratio). These analyses showed a molar ratio Gal:3,6-AnGal:sulfate of 1.00:0.24:0.56 and the absence of L-galactose suggesting the presence of a carrageenan. The usual way to fractionate a system of carrageenans is based on the solubility of the component polysaccharides in solutions of different potas- 
sium chloride concentration; the preparative fractionation yielded three fractions which precipitated between $0.05-0.10 \mathrm{M} \mathrm{KCl}, 1.20-1.25 \mathrm{M} \mathrm{KCl}$ and $1.80-2.00 \mathrm{M} \mathrm{KCl}$, and a main product soluble in $2.00 \mathrm{M}$ $\mathrm{KCl}$. These fractions were analyzed as described for the crude polysaccharide. Chemical analysis of the soluble fraction gave a molar ratio Gal:3,6-AnGal:sulfate of 1.00:0.16:1.47 and a D-:L-galactose ratio of 5.5:1.0. The structural analysis (methylation, FT-IR and ${ }^{13} \mathrm{C}$ NMR) of this fraction will be reported.

Acknowledgements: This work was supported by grants from CONICET (PIA N 6714) and the University of Buenos Aires (TW83).

\section{References and Nores}

1. Usov, A. I.; Ivanova E. G.; Shashkov, A. S. Botanica Marina 1983, 26, 285.

2. Falshaw, R.; Furneaux, R. H.; Stevenson, D. E. Abstracts of the XVIth International Seaweed Symposium 1998, 43.

3. Ciancia, M.; Matulewicz M. C.; Cerezo, A. S. Phytochemistry 1997, 45, 1009.

4. Cases, M. R.; Cerezo A. S.; Stortz, C. A. Carbohydrate Research 1995, 269, 333-341. 